\title{
TOURISM DEVELOPMENT STRATEGY IN KUTAI KARTANEGARA REGENCY OF EAST KALIMANTAN, INDONESIA
}

\author{
Palinggi Yonathan, Dwijatenaya Ida Bagus Made Agung \\ University of Kutai Kartanegara, Indonesia \\ Dewi Mutiara Kartika \\ Balitbangda of Kutai Kartanegara Regency, Indonesia \\ *E-mail: dwijatenaya@yahoo.co.id
}

\begin{abstract}
The right strategy is needed for sustainable tourism development in Kutai Kartanegara. Internal and external considerations are taken into account in the plan. The aim of this study is to look at the development strategy in Kutai Kartanegara Regency East Kalimantan for tourism in Kumala Island Tenggarong. The data was gathered by using (key person). The SWOT analysis method was used in this study. The tourism growth plan in Kutai Kartanegara Regency is in cell 3, which supports the turn-around strategy, according to the SWOT analysis method. According to the SWOT analysis, the issues identified in Kutai Kartanegara Regency's tourism growth strategy are: 1) increasing promotion of Kumala Island tourism as a development center for Kutai and Dayak culture, and 2) maximizing investor use of galleries and homestays, 3) Increasing the budget for tourism infrastructure to support the development of a growing and high-demand tourist region, 4) improving skilled manpower in tourism management to support the development of an ecotourism area, and 5) improving tourist attractions in cultural development (the existence of lamin house).
\end{abstract}

\section{KEY WORDS}

Strategy, development, Kumala Island, tourism.

In Indonesia, the Sustainable Development Goals have become the bedrock of progress. The president of the Republic of Indonesia issued Regulation No. 59 of 2017 on the implementation of the achievement of sustainable development goals, which states that sustainable economic development and wealth are concerned with environmental protection. The implementation of the Sustainable Development Goals in Presidential Regulations Number 59 in 2017 includes, among other things, ensuring the availability of clean water management and sustainable sanitation for all; increasing inclusive and sustainable economy development, comprehensive and productive employment opportunities, and decent vacancy for all; as well as strengthening infrastructure, promoting a more prosperous and equitable economy, and fostering creativity.

According to the aforementioned presidential regulations, tourism development in Kutai Kartanegara Regency East Kalimantan should focus on sustainable tourism built on the sapta pesona base, which includes stability, orderliness, cleanliness, serenity, elegance, humility, and memory. Strategy is a method for achieving the objectives (Rangkuti, 2009). According to Day and Wensley in Rangkuti (2009), there are two factors that enable an organization to be better than its rivals and both are (1) labor abilities and resource capacities, and (2) competitive adventive, which is the competitive excellence caused by the organization's choice of strategy to capture opportunities. SWOT analysis is a form of strategy analysis that is widely used.

SWOT analysis examines internal or external condition of an organization which will be used as the basis of designing strategy and working program. While the internal analysis covers the assessment on strength and weakness factors, the external analysis covers opportunity and threat factors. Rangkuti (2009) explained that SWOT analysis is a systematic identification of various factors in order to formulate strategy. This analysis is based on the 
rationale that could optimize the strength and opportunities, while at the same time minimize the weakness and threats. Furthermore, it is stated that the performance of an organization is determined by the combination of internal strategic factor analysis summary and external factor strategic analysis summary. In developing tourism in Indonesia, each region has their own strategies. Those strategies are; (1) Strength Opportunities (SO) strategy which utilizes the power possessed by an organization/ tourism destination that is being developed. This strategy is discussed by the research from Suharto (2016); Sugianti (2016); Ajmera (2017), Larasati and Rahmawati (2017); Palit, et.al (2017); and Sutrisno (2018), (2) WeaknessOpportunities (WO) strategy which utilizes the existing opportunity by minimizing the weakness. This strategy is further elaborated in the research result of Brahmanto, et.al. (2017), Hermawan (2017), and Irfan and Apriani (2018), (3) Weaknesses-Threats (WT) strategy is being used in defensive circumstances and implemented to minimize the existing weakness and avoid threats. This strategy is reflected in the research result of Adityaji (2018). Research related with the tourism development strategy has also been done by other researchers such as Rohmadin (2016), Arif and Syam (2017), Delita, et.al (2017), Wilopo and Hakim (2017), Sanjaya (2018), and Tatali, et.al (2018).

SWOT approach strategy is not exclusive to tourism sector only. All sectors of development have utilized SWOT approach strategy as their development model. Among the researches which has used SWOT model as its strategy approach are Desmaryani (2016), Holtgrave and Greenwald (2016), Kapoor, et.al. (2016), Susianti (2017), Genta, et.al (2018), ongying Li (2018), Swapna, B (2018), Abbasi, et.al. (2019) and Bocanegra-Valle (2019). The goal of this study is to analyze tourism development strategy in Kutai Kartanegara Regency on the case of Kumala Island in Tenggarong

\section{METHODS OF RESEARCH}

The research design is a plan and structure of investigation which is formulated to obtain findings to the research questions (Kerlinger, 2006). This study aims to determine the strategy which will be used to develop tourism in Kumala Island Tenggarong Kutai Kartanegara regency East Kalimantan Indonesia. For this reason, the research design used is a quantitative research design with quantitative descriptive format.

Bungin (2010) stated that descriptive format will explain and summarize various conditions, situations, or variables which emerge in the society. Furthermore Kuncoro (2009) stated that descriptive research covers data collection to answer questions regarding the last status of research subjects.

Kutai Kartanegara Regency as one of the Regencies in East Kalimantan Province consists of eighteen sub-districts. Those sub-districts possessed resources, either renewable resources or non-renewable resources. In addition to that, Kutai Kartanegara regency has potential tourism destination which could be developed such as Kumala Island Tenggarong. This research was done in three months from October until December 2019. All stakeholders in Kutai Kartanegara Regency; policy maker officials in Kutai Kartanegara Regency, local public figures, Kumala Island Tourism management, and visitors became the key informants in this research.

The instrument used was questionnaire (structured interview) (Sugiyono, 2012). Instrument was arranged by the researcher based on literature review. Primary and secondary data were used as the source of data in this study. The primary data that has been collected were the data of opinion and perspectives toward Kumala Island tourism development strategy in Kutai Kartanegara Regency, those opinion and perspectives were; concerning strength, weakness as well as threats. The collection of primary data was done by the researchers through distributing questionnaire and deep interview towards all stakeholders. The primary data was collected when the tourist destination was not closed yet as the impact of COVID 19 breakout. The secondary data was obtained from collecting the data from previous study and relevant literature review. The secondary data source came from; Central Bureau of Statistics (Badan Pusat Statistik or BPS), Regional Development Planning Agency of Kutai Kartanegara Regency (Badan Perencanaan Pembangunan 
Daerah or Bappeda), Regional Research and Development Agency of Kutai Kartanegara Regency (Badan Penelitian and Pengembangan Daerah or BALITBANGDA), Tourism Regional Apparatus Organization (Organisasi Perangkat Daerah or OPD) and data from relevant institutions.

Data collection techniques in this study consists of questionnaire, structured interview, observation and documentation. Techniques of data collection are explained below.

- Structured Interview. In order to support the quantitative study, a structured interview technique is used in this research. Structured interview is a technique of data collection by using questionnaire as research instrument which has been prepared before by the relevant researcher with variables that has been researched (Sugiyono, 2012). Kerlinger (2006) stated that in structured interview, the questions, orders and the words formulation has been fixed and cannot be changed.

- Non-participant and unstructured observation. Non-participant observation is a method where the researcher comes to the place where the activities of the people being observed, but not involved in the activities. Unstructured observation aims to develop observation focus and a systematically unprepared observation, it does not use formal instruments, but uses only observation signs (Sugiyono, 2012). Observation that was done covered activities done in Kumala island tourist destination, visitors, tourist destination facilities availability, etc.

- Documentation. A note of important events that has passed is called documentation (Sugiyono, 2012). The documents can be found in form of writing, pictures, or other monumental arts of a person. Documentation technique is a complementary for the observation and interview techniques. The documents that were used comprised of Kutai Kartanegara document in numbers, Kutai Kartanegara tourism profile, and etc, as well as pictures related with business and activities conducted in the area of Kumala Island.

In order to reach the aim of the study, descriptive analysis technique is used to analyze the data which has been collected Descriptive analysis is applied to answer research problems and provide systematic and logical elaboration between the data obtained and the examined problem. The analysis method that is used is SWOT analysis.

A study framework of strength, weakness, and external opportunities, as well as threats, is applied to provide a simple method to estimate the best way to implement a strategy. This instrument is helping the strategist to determine their targets and the focus of their attention. SWOT analysis theory is being used to plan something related with SWOT.

SWOT stands for Strength, Weakness, Opportunity, and Threats. SWOT is commonly used to analyze a condition where planning is required. According to Rangkuti (2009), SWOT is an approach to identify several factors systematically to formulate a service strategy. This analysis is based on the rationale to optimize opportunities but at the same time minimizing the weakness and threats. SWOT analysis compares the internal and external factors.

Following are the steps and explanation on SWOT:

1. Each factor in IFAS and EFAs is weighted down according to the level of importance on a scale starting from 1 (not important) until 4 (very important). The weight of the score from each factor is normalized until the overall weight of the score is 1 ;

2. Each factor in IFAS and EFAS is given a score or rating on a scale of 1 to 4 based on the influence of the factors on the commodities. Factors with positive impact (very good) get 4, meanwhile, negative factor get 1 ;

3. Each amount of weight and rating are the average score given by the respondent;

4. Multiplying the weight and the rating of each factor to get the score of each factor;

5. Summing up the score of internal factors to get the total internal factors score. Do the same thing for the external factors. The total of internal factors score and the total of external factors score become references to determine strategic action that will be done in regards to the existence and development of tourism area in Kumala Island Tenggarong.

Based on the consideration of crossing factors which includes strength, weakness, opportunities and threat which is written into matrix of $2 \times 2$, the steps for the tourism 
development strategy of Kutai Kartanegara regency are formulated which are summarized into the SO strategy (Strength-Opportunities), ST strategy, WO strategy and WT strategy. As shown in table 1.

Table 1 - SWOT Matrix, 2020

\begin{tabular}{llll}
\hline & & External Factors & \\
\cline { 3 - 4 } & & Opportunity $(\mathrm{O})$ & Threat $(\mathrm{T})$ \\
\hline Internal & Strength (S) & Strategy of & Strategy of \\
Factors & \multirow{2}{*}{ Weakness (W) } & S-O (aggressive strategy) & S-T (Diversification strategy) \\
& & Strategy of & Strategy of \\
& & W-O (turn around strategy) & W-T (defensive strategy) \\
\hline
\end{tabular}

Source: Rangkuti, 2019.

\section{RESULTS AND DISCUSSION}

General description of the research object. Kumala Island Tourism area as the object of the study is located in the middle of Mahakam River delta in Tenggarong Kutai Kartanegara East Kalimantan. A bridge that connects the city of Tenggarong and Kumala Island has been built in this tourism area. Kumala Island has been built as a tourism object since 2000. This tourism object was officiated in 2002. The small island covering an area of 76 hectares has been equipped with various tourist facilities. Kumala Island Tourism in Tenggarong seeks to combine natural tourism and man-made tourism. The government of Kutai Kartanegara Regency makes serious efforts to turn this tourism object into the center of recreation and tourism, whether for domestic or international tourists. Thus, strategy development of this tourism area has been made. This small island which looks similar to a boat in the middle of a river requires special attention if this place is to be directed as one of the leading tourist destinations.

Several matters should get the attention of the strategist, and that is optimizing the rides that have been owned. Rides which utilization should be optimized such as; Sky Tower, Mini Trains, Cottage, etc. Tourism object gives benefits to the society; which is the increase of income for the community. The gallery in Kumala Island also needs improvement and should be optimized. Another ride that should be addressed is the mini train. The available facilities like cottage are also not well maintained, thus no visitors are willing to stay in the cottage they tend not to be maintained anymore.

Table 2 - Total visits to Kumala Island tourism in Tenggarong, in 2017and 2018

\begin{tabular}{lllll}
\hline \multirow{2}{*}{ MONTH } & \multicolumn{3}{l}{ TOTAL VISITS } & \multicolumn{2}{l}{ YEAR 2018 } \\
\cline { 2 - 5 } & \multicolumn{2}{l}{ YEAR 2017 } & $\%$ & NUMBER \\
\cline { 2 - 5 } & NUMBER & 15.46 & 50715 & 17.63 \\
2 & 60194 & 5.56 & 15844 & 5.51 \\
3 & 21644 & 5.70 & 16294 & 5.67 \\
4 & 22174 & 6.62 & 16161 & 5.62 \\
5 & 25768 & 7.27 & 18657 & 22.18 \\
6 & 28315 & 22.00 & 63775 & 10.28 \\
7 & 85631 & 12.05 & 29559 & 4.81 \\
9 & 46908 & 3.62 & 13830 & 3.84 \\
10 & 14100 & 6.47 & 11032 & 3.44 \\
11 & 25200 & 3.70 & 9895 & 3.28 \\
\hline
\end{tabular}

Source: Kutai Kartanegara Regency Tourism Office.

Taking into account the current condition of Kumala Island tourism area, many things need to be addressed. Management of tourism areas should be improved if they do not want to be left by the visitors. Based on this condition, the researcher is interested in examining the strategies that should be used by the government or the management of Kumala Island tourism area. It is known that human resources also determine the sustainability of a tourist 
attraction. For this reason, efforts to improve the human resources, both the management and the community of this area should be done.

Kumala Island tourism area was officiated in 2002. However, the number of visitors to this tourism object did not increase at all. As provided in Table 2, it is shown that for the last two years the number of visits to this tourism object has decreased. The decline in the number of visitors made the local government attempted to do several efforts to increase the number of visitors to this tourism object.

Tourism Development Strategy. David (2008) explained that the strategist is the person who is most responsible for the success and failure of an organization. The strategist is not only the job of the top executive, but the middle and bottom level of managerial should also be involved in the strategy planning. The tools used commonly to analyze strategy is SWOT analysis. SWOT analysis is an internal or external condition of an organization that will be used as the foundation to design strategy and working program. The internal analysis covers assessment towards the strength and weakness. Meanwhile, the external analysis covers the opportunity and threat.

To determine the tourism development strategy in Kutai Kartanegara Regency East Kalimantan particularly the tourism area in Kumala Island Tenggarong, SWOT analysis approach was implemented in this research, as explained below. SWOT analysis is an identification of various factors systematically to formulate tourism development strategy in Kumala Island. This analysis is based on the rationale that could optimize the strength and opportunities, while at the same time minimizing the weakness and threat. The followings are the details on the strength, weakness, opportunity, and threat to construct tourism development strategy in Kumala Island Tenggarong Kutai Kartanegara Regency.

A. Internal Factors are the strength and the weakness possessed by Kutai Kartanegara Regency in order to develop Kumala Island tourism.

1. The strengths are as follows:

1) S1: Various tourist attractions;

2) S2: Abundant water source;

3) S3: As a strategic choice of place;

4) S4: Support from regional government;

5) S5: The hospitality of the community;

6) S6: Kumala Island's amenity.

2. The weaknesses are as follows:

1) W1: Lack of promotion;

2) W2: The souvenir gallery is less representative;

3) W3: Poorly maintained environmental sanitation;

4) W4: Homestays in Kumala Island are not utilized properly and effectively;

5) W5: Lack of tourist attraction;

6) W6: Low level of awareness in preserving tourist attractions;

7) W7: Budget limitations for the infrastructures of tourist attractions;

8) W8: Lack of professional manpower in managing the tourism object.

B. External Factors are the opportunities and threats possessed by Kutai Kartanegara regency to design tourism development strategy in Kumala Island Tenggarong:

1. Opportunities consists of:

1) O1: The existence of regional autonomy provides freedom and independence to tourism potential;

2) O2: Kumala Island becomes an attractive tourism choice;

3) O3: Investment for the investors;

4) O4: Increasing environmental awareness in the tourism area of Kumala Island;

5) O5: As the center of cultural development (with the existence of lamin house);

6) O6: As tourism area that is increasingly developing and in demand;

7) 07: As an area that can be developed as ecotourism.

2. Threats consists of:

1) T1: There are other tourist attractions around Kumala Island (museum, planetarium); 
2) T2: The impediment to environmental sanitation;

3) T3: The mining activities located at the upstream of Tenggarong River and Mahakam Rive are impediments and threats to the water sanitation;

4) T4: Incessant and relentless strategy drafting to tourism by regencies/cities in East Kalimantan province.

Based on the internal and external factors which have been identified to plan the tourism development strategy in Kumala Island Tenggarong Kutai Kartanegara Regency hereinafter those items are arranged into SWOT table. The result of internal and external factors is explained as provided in Table 3 and 4 below.

Table 3 - The result of Internal Factors Analysis, 2020

\begin{tabular}{|c|c|c|c|c|c|}
\hline No & & Internal Strategic Factors & \multirow[t]{2}{*}{$\begin{array}{l}\text { Average } \\
\text { Rating } \\
\text { (a) } \\
\end{array}$} & \multirow[t]{2}{*}{$\begin{array}{l}\text { Average } \\
\text { Weight } \\
\text { (b) }\end{array}$} & \multirow[t]{2}{*}{$\begin{array}{l}\text { Average } \\
\text { Score } \\
(a \times b)\end{array}$} \\
\hline & & Strength & & & \\
\hline 1 & S1 & Various tourism attractions & 3.40 & 0.05 & 0.16 \\
\hline 2 & S2 & Abundant water source & 3.00 & 0.03 & 0.09 \\
\hline 3 & S3 & As a strategic choice of place & 3.47 & 0.06 & 0.20 \\
\hline 4 & S4 & The support from the regional government & 3.53 & 0.06 & 0.20 \\
\hline 5 & S5 & The hospitality of the community & 3.27 & 0.05 & 0.16 \\
\hline \multirow[t]{3}{*}{6} & S6 & Kumala Island's amenity & 3.47 & 0.08 & 0.28 \\
\hline & & SUB TOTAL OF STRENGTH & & 0.32 & 1.09 \\
\hline & & Weakness & & & \\
\hline 7 & W1 & Lack of promotion & 2.20 & 0.03 & 0.07 \\
\hline 8 & W2 & The souvenir gallery is less representative & 2.73 & 0.06 & 0.18 \\
\hline 9 & W3 & Poorly maintained environmental sanitation & 3.00 & 0.08 & 0.25 \\
\hline 10 & W4 & Homestays in Kumala Island are not utilized properly and effectively. & 2.80 & 0.09 & 0.25 \\
\hline 11 & W5 & Lack of tourist attraction & 2.93 & 0.09 & 0.27 \\
\hline 12 & W6 & Low level of awareness in preserving tourist attractions & 2.80 & 0.09 & 0.26 \\
\hline 13 & W7 & Budget limitations for the infrastructures of tourist attractions & 3.13 & 0.12 & 0.37 \\
\hline \multirow[t]{2}{*}{14} & W8 & Lack of professional manpower in managing the tourism & 3.07 & 0.11 & 0.32 \\
\hline & & SUB TOTAL OF WEAKNESS & & 0.68 & 1.97 \\
\hline \multicolumn{2}{|c|}{ TOTAL } & & & 1.00 & 3.06 \\
\hline
\end{tabular}

Source: Research results.

Table 4 - The Result of External Factors Analysis, 2020

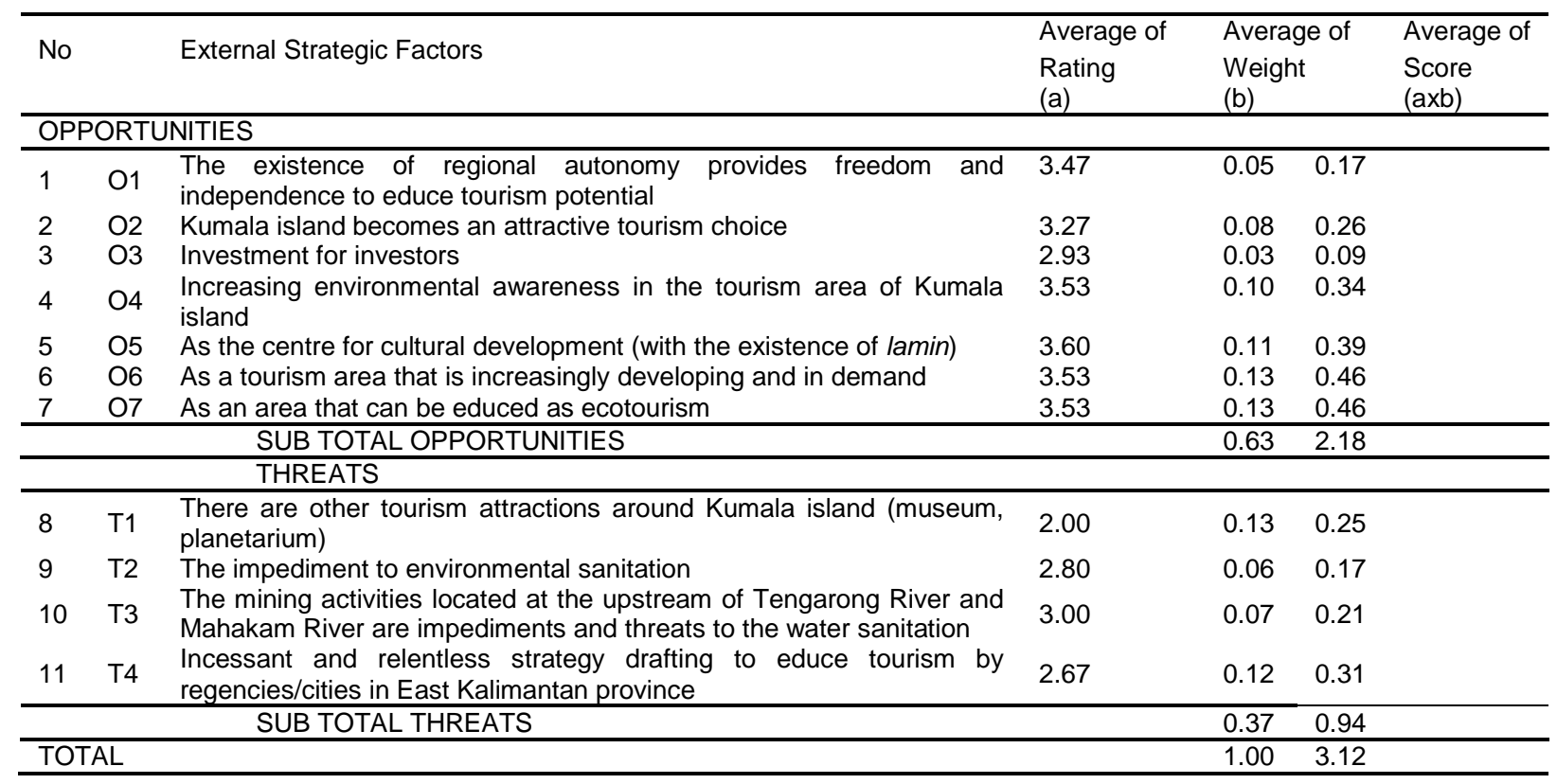

Source: Research Outcome.

According to the outcome of internal and external factors analysis summarized into IFAS and EFAS table, the tourism development strategy of Kutai Kartanegara can then be 
deliberated. It can be briefly described in the following narration. In the beginning, Regional Government Budget (Anggaran Pendapatan and Belanja Daerah - APBD) Kutai Kartanegara Regency was extremely dependent on oil and gas. Then, the oil and gas reserve were gradually depleted. Therefore, Kutai Kartanegara Regency strived to advance economy sectors outside mining, i.e., tourism sector. Kutai Kartanegara Regency, which is blessed with exquisite panoramic nature, has made use of it by turning it into tourist attractions, one of which is Kumala island. To ensure the sustainability of Kumala Island's development goal, a proper development strategy is needed. As one of the analysis tools for strategy development, SWOT analysis was implemented as described in the following.

1. SWOT Diagram.

The internal factor analysis results as presented in Table 2 shows the Strength factor of 1.09. Strength factor is the special competencies possessed by Kutai Kartanegara Regency in accordance with the advancement of Kumala island tourism area. The internal factor analysis also shows the Weakness factor of 1.97. Weakness factor is the limitations or shortcomings possessed by Kutai Kartanegara Regency in accordance with the advancement of Kumala island tourism area. Based on the analysis of Strength and Weakness factors, the difference in the number of internal factor values (Strength Weakness) is -0.88 (minus zero point eight eight).

The external factor analysis in table 3 shows the Opportunities factor of 2.18. Opportunities are various advantageous circumstances possessed by Kutai Kartanegara Regency in proliferating Kumala island tourism area. The Threats factor of 0.94 is also seen in the assessment of external factors. Kutai Kartanegara Regency faces threats from negative environmental factors. After obtaining the results of the Opportunities and Threats factors, the difference between these external factors (Opportunities - Threats) can be determined, which is 1.24. The difference of the total value of internal and external factors is further organized and compiled into SWOT diagram presented in Figure 1.

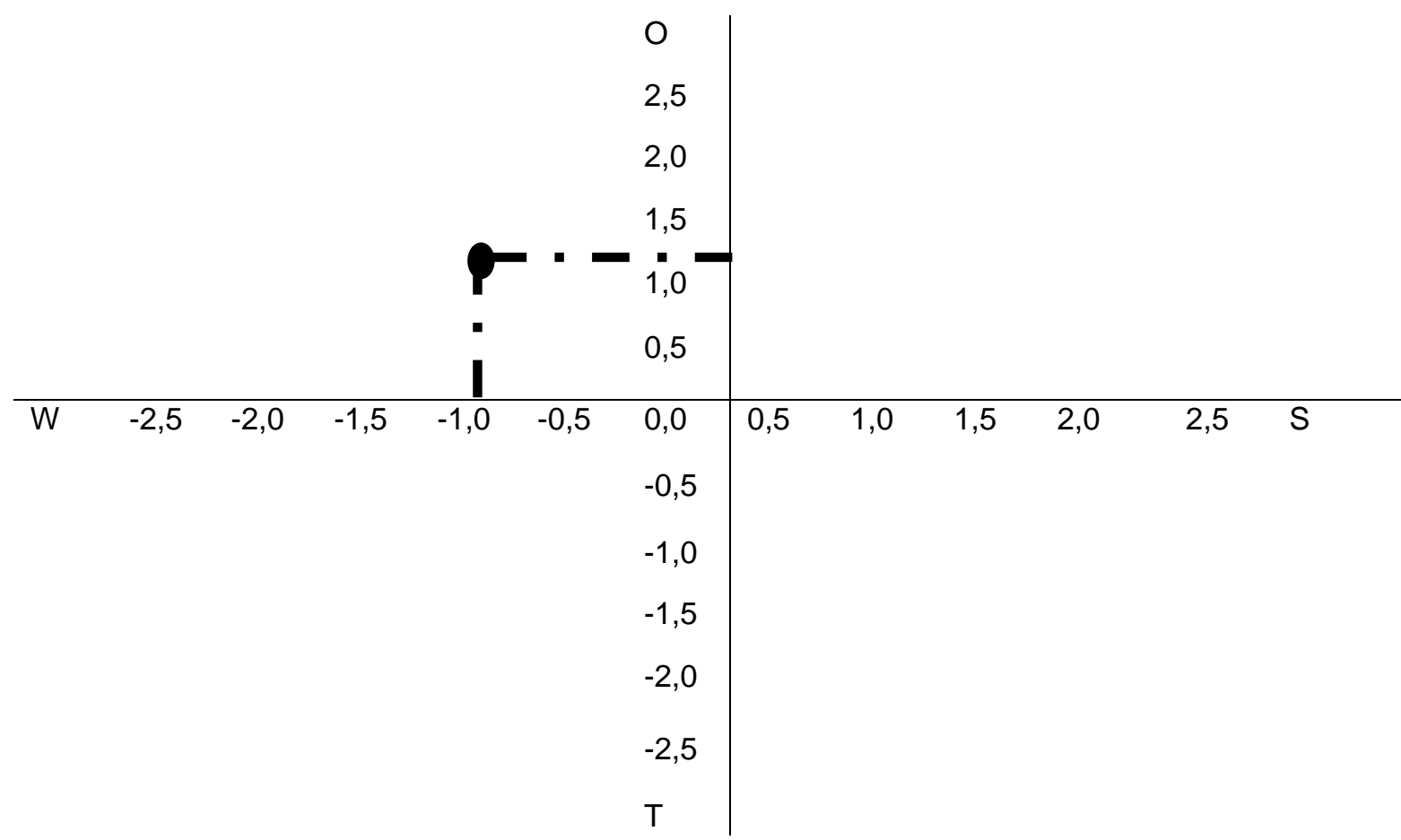

Figure 1 - The SWOT Diagram of the Tourism Development Strategy of Kumala island, Tenggarong, Kutai Kartanegara Regency, 2020 (Source: Data processing results)

Table 5 - SWOT Matrix for the development strategy formulation of Kumala island Tenggarong, 2020 


\begin{tabular}{|c|c|c|}
\hline & STRENGTHS (S) & WEAKNESSES (W) \\
\hline EXTERNAL & $\begin{array}{l}\text { - Various tourist attractions } \\
\text { - Abundant water source } \\
\text { - As a strategic choice of place } \\
\text { - The support from the regional } \\
\text { government } \\
\text { - The hospitality of the community } \\
\text { - Kumala island's amenity }\end{array}$ & $\begin{array}{l}\text { - Lack of promotion } \\
\text { - The souvenir gallery is less } \\
\text { representative } \\
\text { - Poorly maintained environmental } \\
\text { sanitation } \\
\text { - Homestays in Kumala island are } \\
\text { not utilized properly and } \\
\text { effectively } \\
\text { - Lack of tourist attractions } \\
\text { - Low level of awareness in } \\
\text { preserving tourist attractions } \\
\text { - Budget limitations for the } \\
\text { infrastructures of tourist } \\
\text { attractions } \\
\text { - Lack of professional manpower } \\
\text { in managing the tourism }\end{array}$ \\
\hline OPPORTUNITIES (O) & $\mathrm{S}-\mathrm{O}$ & $\mathrm{W}-\mathrm{O}$ \\
\hline $\begin{array}{l}\text { - The existence of regional } \\
\text { autonomy provides freedom and } \\
\text { independence to educe tourism } \\
\text { potential } \\
\text { - Kumala island becomes an } \\
\text { attractive tourism choice } \\
\text { - Investment for investors } \\
\text { - Increasing environmental } \\
\text { awareness in the tourism area of } \\
\text { Kumala island } \\
\text { - As the centre for cultural } \\
\text { development (with the existence } \\
\text { of lamin) } \\
\text { - As a tourism area that is } \\
\text { increasingly developing and in } \\
\text { demand } \\
\text { - As an area that can be educed } \\
\text { as ecotourism }\end{array}$ & 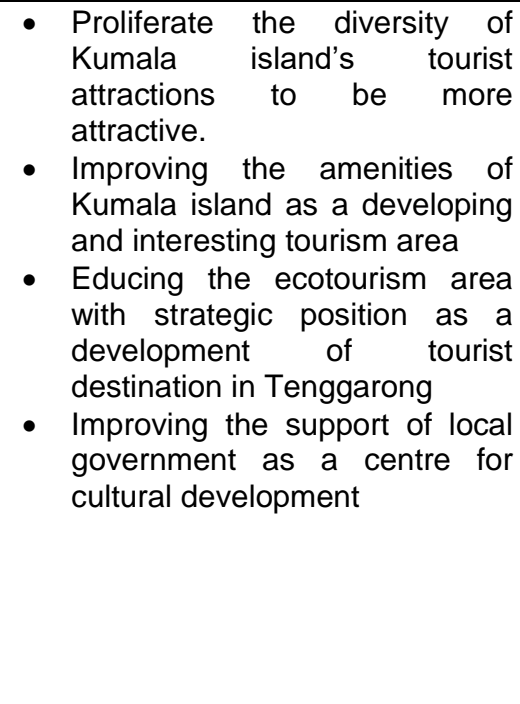 & $\begin{array}{l}\text { - Increasing the promotion of } \\
\text { Kumala island tourism as a } \\
\text { development centre for Kuta } \\
\text { and Dayak culture } \\
\text { - Optimizing investor in utilizing } \\
\text { galleries and homestays } \\
\text { - Increasing the budget for the } \\
\text { infrastructures of the tourism in } \\
\text { order to support the developing } \\
\text { tourism area and increasingly in } \\
\text { demand } \\
\text { - The improvement of professional } \\
\text { manpower in the tourism } \\
\text { management to support the } \\
\text { development of ecotourism area } \\
\text { - The improvement of tourist } \\
\text { attractions in cultural } \\
\text { development (the existence of } \\
\text { Lamin house) }\end{array}$ \\
\hline THREATS $(T)$ & $S-T$ & $W-T$ \\
\hline $\begin{array}{l}\text { - There are other tourist } \\
\text { attractions around Kumala } \\
\text { island (museum, planetarium) } \\
\text { - The impediment } \\
\text { environmental sanitation } \\
\text { - The mining activities located at } \\
\text { the upstream of Tengarong } \\
\text { River and Mahakam River are } \\
\text { impediments and threats to the } \\
\text { water sanitation } \\
\text { - Incessant and relentless } \\
\text { strategy drafting to educe } \\
\text { tourism by regencies/cities in } \\
\text { East Kalimantan province }\end{array}$ & 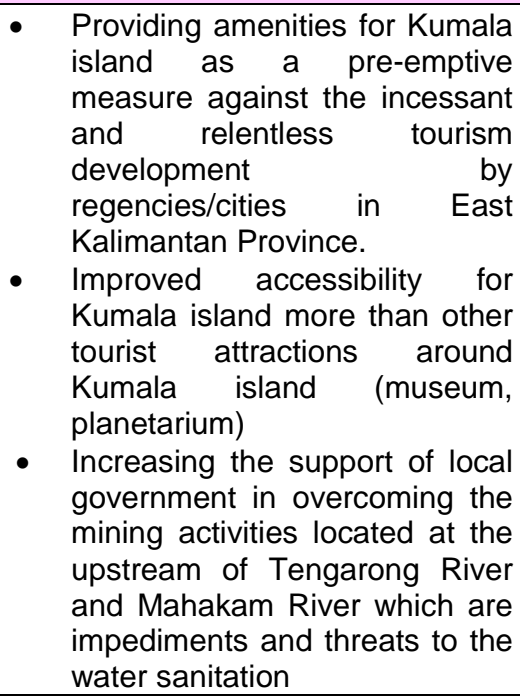 & $\begin{array}{l}\text { - Increasing the budget for } \\
\text { Kumala island's infrastructures } \\
\text { as a pre-emptive measure } \\
\text { against the incessant and } \\
\text { relentless strategy drafting to } \\
\text { educe tourism by } \\
\text { regencies/cities in East } \\
\text { Kalimantan province } \\
\text { - The improvement of professional } \\
\text { manpower in managing Kumala } \\
\text { island as a tourist attraction to } \\
\text { exceed the HR (Human } \\
\text { Resources) of those other tourist } \\
\text { attractions around Kumala island } \\
\text { (museum, planetarium) } \\
\text { - Kickstarting the tourists' } \\
\text { awareness to preserve the } \\
\text { sanitation and cleanliness of } \\
\text { Kumala island tourism }\end{array}$ \\
\hline
\end{tabular}

Source: Research results.

The SWOT diagram above shows that the tourism development strategy of Kumala island Tenggarong is in cell 3, which espouses the turn-around strategy and in accordance with the result from previous study, e.g., Rangkuti (2019), Brahmanto, et al. (2017), 
Hermawan (2017), and Irfan and Apriani (2018). Turn-around strategy, which is necessary to be involved in deciding policies for the tourism development strategy of Kumala island Tenggarong, means that the government has an enormous opportunity in taking actions for educing this tourism. But on the other hand, the government has to address the internal problems, e.g., there are other tourist attractions around Kumala island (museum, planetarium), the impediment to environmental sanitation, the mining activities located at the upstream of Tengarong River and Mahakam River are impediments and threats to the water sanitation, and incessant and relentless strategy drafting to educe tourism by regencies/cities in East Kalimantan province.

\section{SWOT Matrix.}

SWOT matrix is the tool utilized to organize the strategic factors of the tourism development of Kumala island Tenggarong. SWOT matrix elaborates in detail on the strengths and weaknesses in developing the tourism of Kumala island Tengarong, and by utilizing the opportunities and threats in its favour. This SWOT matrix produces 4 possible strategy alternatives, e.g., SO, ST, WO, and WT. According to Rangkuti (2009), the position within cell 3 means it has to apply WO (weaknesses-opportunities) strategy. This strategy is implemented by using the existing opportunities and rectifying the internal problems contained within. This strategy is scrutinized further in the matrix presented in the Table 5.

Strategic issues compiled in the matrix of tourism development strategy of Kutai Kartanegara Regency, East Kalimantan Province, Kumala island tourism, utilize the internal and external factors that are inherently possessed. The possible combinations amongst the factors are as follows: utilizing strengths and opportunities strategy which produces optimal tourism development strategy (S-O), utilizing strengths and reducing threats to espouse the tourism development strategy (S-T), minimalizing weaknesses and utilizing opportunities which allow the increase of regional income through tourism advancement (W-O), and minimalizing weaknesses and transforming threats into advantageous circumstances in order to improve competitiveness and public's interest in visiting tourism area (W-T).

Based on SWOT analysis presented in figure 1 inferred from the quantitative analysis and SWOT matrix in table 5, the implementable strategies on the tourism of Kutai Kartanegara Regency's Kumala island Tenggarong are:

1.) S-O Strategy:

This strategy is created on the basis of the strengths possessed by Kutai Kartanegara Regency in terms of educing the tourism area of Kumala island Tenggarong and utilizing the existing opportunities. The points in this strategy are:

1. Diversifying tourist attractions in Kumala island Tenggarong as an interesting choice of tourist destination;

2. Improving the amenities in Kumala island as a developing and interesting tourism area;

3. Educing the ecotourism area with strategic position as a development of tourist destination in Tenggarong;

4. Improving the support of local government as a centre for cultural development.

2.) S-T Strategy:

This strategy is created on the basis of utilizing strengths and overcoming threats possessed by Kutai Kartanegara Regency in educing the tourism area of Kumala island Tenggarong. The points in this strategy are:

1. Providing amenities for Kumala island as a pre-emptive measure against the incessant and relentless tourism development by regencies/cities in East Kalimantan Province;

2. Improving accessibility for Kumala island more than other tourist attractions around Kumala island (museum, planetarium);

3. Increasing the support of local government in overcoming the mining activities located at the upstream of Tengarong River and Mahakam River which are impediments and threats to the water sanitation.

3.) W-O Strategy: 
This strategy is created on the basis of utilizing opportunities and minimalizing weaknesses possessed by Kutai Kartanegara Regency in educing the tourism area of Kumala island Tenggarong. The points in this strategy are:

1. Increasing the promotion of Kumala island tourism as a development centre for Kutai and Dayak culture;

2. Optimizing investor in utilizing galleries and homestays;

3. Increasing the budget for the infrastructures of the tourism in order to support the developing tourism area and increasingly in demand;

4. The improvement of professional manpower in the tourism management to support the development of ecotourism area;

5. The improvement of tourist attractions in cultural development (the existence of Lamin house).

4.) W-T Strategy:

This strategy is created on the basis of defensive actions and struggles to minimalize weaknesses and avoiding threats in educing the tourism of Kutai Kartanegara Regency's Kumala island Tenggarong. Based on the SWOT matrix analysis, the points in this strategy are:

1. Increasing the budget for Kumala island's infrastructures as a pre-emptive measure against the incessant and relentless strategy drafting to educe tourism by regencies/cities in East Kalimantan province;

2. The improvement of professional manpower in managing Kumala island as a tourist attraction to exceed the HR (Human Resources) of those other tourist attractions around Kumala island (museum, planetarium);

3. Kickstarting the tourists' awareness to preserve the sanitation and cleanliness of Kumala island tourist attraction.

Strategic issues compiled in the matrix of tourism development strategy of Kutai Kartanegara Regency, East Kalimantan Province, Kumala island tourism area, refers to the quantitative analysis result in figure 1, which resides in cell 3 (W-O Strategy). Thus, there are 5 (five) top strategy points as the priority in tourism development strategy of Kutai Kartanegara Regency for Kumala island Tenggarong. The strategic issues or points as referred to are explained as follows:

1.) Increasing the promotion of Kumala island tourism as a development centre for Kutai and Dayak culture. The Kutai customary culture refers to its annual event, i.e., Erau Adat Kutai. This event is held in the effort of preserving the customary tradition of the Sultanate of Kutai Kartanegara Ing Martadipura. Erau is derived from the word Eroh which means lively, boisterous, and full of joy. At first, this traditional ceremony was performed for the Tijak Tanah Aji Batara Agung Dewa Sakti (The First King of The Kutai Kartanegara Kingdom) procession. Dayak customary culture is reflected in the existence of the Dayak lamin house. The architecture of lamin house has unique and interesting characteristics, e.g., its rectangular shape, built on stilts, and decorated with statues, carvings, and paintings with typical Dayak motif. If the escalation of promotion is consistent, then the existence of Kumala island tourism will be even more egregious among the local and international tourists

2.) Optimizing investor in utilizing galleries and homestays. Galleries are one of the supports owned by Kumala island tourism. Galleries that are quintessential will give its own satisfaction for tourists, as well as homestays, but the superintendence of both is not eligible to be categorized as optimal. Therefore, galleries and homestays available in Kumala Island should be superintended well, and this is where investors are needed

3.) Increasing the budget for the infrastructures of the tourism in order to support the developing tourism area and increasingly in demand. Kumala Island Tenggarong is one of the tourist destinations built by Kutai Kartanegara Regency. Recently, both the development and the maintenance of the infrastructures are not sufficient. One of the examples to prove the point is the sky tower and the cable cars are still not functioning. Thus, increasing the budget for the infrastructures is the right action to take; 
4.) The improvement of professional manpower in the tourism management to support the development of ecotourism area. Human resources in tourism is the determining factor in the success of a tourism area. Consequently, the improvement of professional manpower in the tourism management is of great importance;

5.) The improvement of tourist attractions in cultural development (the existence of Lamin house). Lamin houses available in Kumala island tourism are for art and culture exhibitions. Based on the result of the researchers' observation, the art and culture exhibitions are not quintessential, and thus the tourist attractions improvement strategy in Kumala island needs to be implemented.

\section{CONCLUSION}

Based on the result and study of this research, the conclusion is as follows: the SWOT diagram shows that the tourism development strategy of Kutai Kartanegara Regency for Kumala Island Tenggarong is in cell 3, which supports the turn-around strategy. Turn-around strategy that needs to be executed in deciding the policies for the development of Kutai Kartanegara Regency, East Kalimantan Province, means the government has big opportunities and chance to educe Kumala Island in a sustainable way. Kumala Island also needs to be attended and educed, coal mining businesses that continuously interfere with the water sanitation, and the incessant tourism promotion by other regencies to promote their own tourism.

Based on the analysis result, there are 5 (five) top strategies as the priority in tourism development strategy of Kutai Kartanegara Regency for Kumala island Tenggarong according to the SWOT analysis aforementioned as the priority. The strategies are: 1) Increasing the promotion of Kumala island tourism as a development centre for Kutai and Dayak culture, 2) Optimizing investor in utilizing galleries and homestays, 3) Increasing the budget for the infrastructures of the tourism in order to support the developing tourism area and increasingly in demand, 4) The improvement of professional manpower in the tourism management to support the development of ecotourism area, 5) The improvement of tourist attractions in cultural development (the existence of Lamin house).

\section{ACKNOWLEDGEMENTS}

Researchers would like to convey thanks to parties who have been helpful along the journey to finish this research. Special thanks to Dean of the Faculty of Agriculture and Head of Institute of Research and Community Service Unikarta Tenggarong for the permission to pursue this research. We would also like to thank Head of Research and Development Agency and Department of Tourism and Culture Kutai Kartanegara Regency and for the endless support to finish this research. We would also like to convey gratitude to reviewers for their time to revise for the betterment of this paper.

\section{REFERENCES}

1. Abbasi, Fatemeh, Javier Esparcia, and Heshmat A. Saadi. (2019). From Analysis To Formulation of Strategies for Farm Advisory Services (Case Study: Valencia-Spain). An Application Through SWOT And QSPM Matrix. Europ. Countrys, 11(1): 43-73.

2. Adityaji, Rizki. (2018). Formulasi Strategi Pengembangan Destinasi Pariwisata dengan Menggunakan Metode Analisis SWOT: Studi Kasus Kawasan Pecinan Kapasan Surabaya. Jurnal Pariwisata Pesona, 03(1): 19-32.

3. Ajmera, Puneeta. (2017). Ranking the strategies for Indian medical tourism sector through the integration of SWOT analysis and TOPSIS method. International Journal of Health Care Quality Assurance, 30(8): 668-679.

4. Arif, Muhammad and Alexander Syam. (2017). Strategi Pengembangan Objek Wisata Pantai Sumedang di Kecamatan Ranah Pesisir Kabupaten Pesisir Selatan. Jurnal Kepemimpinan and Pengurusan Sekolah, 2(2): 191-200. 
5. Bocanegra-Valle, Ana. (2019). Building a Reputation in Global Scientific Communication: A SWOT Analysis of Spanish Humanities Journals. Canadian Journal of Sociology, 44(1): 39-66.

6. Brahmanto, Erlangga, Hary Hermawan and Faizal Hamzah. (2017). Strategi Pengembangan Kampung Batu Malakasari Sebagai Daya Tarik Minat Khusus. Jurnal Media Wisita, 15(2): 588-600.

7. Bungin, H.M. Burhan. (2010). Metodologi Penelitian Kuantitatif. Jakarta: Prenada Media Group.

8. David, Fred R. 2008. Strategic Management, Manajemen Strategis. (Edisi 10). (Ichsan Setyo Budi. Pentj.). Jakarta: Salemba Empat.

9. Delita, Fitra, Elfayetti, and Tumiar Sidauruk. 2017. Analisis SWOT untuk Strategi Pengembangan Obyek Wisata Pemandian Mual Mata Kecamatan Pematang Bandar Kabupaten Simalungun. Jurnal Geografi, 9(1). 41-52.

10. Delita, Fitra, Elfayetti, and Tumiar Sidauruk. (2017). Analisis SWOT untuk Strategi Pengembangan Obyek Wisata Pemandian Mual Mata Kecamatan Pematang Bandar Kabupaten Simalungun. Jurnal Geografi, 9(1): 41-52.

11. Desmaryani, Susi (2016). The Implementation of SWOT Analysis of People Economic Empowerment Business Loan (KUPEM) in Jambi Province. Jurnal Bina Praja, 8(2):305315.

12. Genta, Muhammad, Usman M. Tang, Khairul Anwar, Sri Wahyuni, and Syahril. (2018). Sustainable strategy of charcoal (Panglong Arang) management in the Bengkalis Regency. EurAsian Journal of BioSciences, 2018(12): 313-320.

13. Hermawan, Hary. (2017). Pengembangan Destinasi Wisata Pada Tingkat Tapak Lahan Dengan Pendekatan Analisis Swot. Pariwisata, IV(2): 64-74.

14. Holtgrave, David R. and Robert Greenwald. (2016). A SWOT Analysis of the Updated National HIV/AIDS Strategy for the U.S., 2015-2020. AIDS Behav, 2016(20): 1-6.

15. Hongying Li. (2018). Research on Development Strategy of Tourism Industry in the Southern Sichuan Economic Zone. Journal of Service Science and Management, 2018(11): 83-93.

16. Irfan, Pahrul and Apriani. 2018. Analisa Strategi Pengembangan E-Tourism Sebagai Promosi Pariwisata Di Pulau Lombok. Indonesian Journal on Networking and Security, 7(1): 7-11.

17. Kapoor, Ritika, Wei Chuen Tan-Koi, and Yik-Ying Teo. (2016). Role of pharmacogenetics in public health and clinical health care: a SWOT analysis, European Journal of Human Genetics, 2016(24): 1651-1657.

18. Kerlinger, Fred N. (2006). Asas-asas Penelitian Behavioral. (Landung R. Simatupang, Pentj). Yogyakarta: Gadjah Mada University Press.

19. Larasati, Ni Ketut Ratih and Dian Rahmawati. (2017). Strategi Pengembangan Pariwisata Budaya yang berkelanjutan Pada Kampung Lawas Maspati Surabaya. JURNAL TEKNIK ITS, 6(2): 529-533.

20. Menteri Hukum and Hak Asasi Manusia Republik Indonesia. (2017). Pelaksanaan Pencapaian Tujuan Pembangunan Berkelanjutan. Jakarta: Menteri Hukum and Hak Asasi Manusia Republik Indonesia.

21. Palit, Ireine Gratia, Celcius Talumingan, and Grace A.J. Rumagit. 2017. Strategi Pengembangan Kawasan Agrowisata Rurukan. Agri-SosioEkonomi Unsrat, 13(2A): 21 34.

22. Rangkuti, Feddy. (2009). Analisis SWOT, Teknik Membedah Kasus Bisnis. Jakarta: Penerbit PT. Gramedia Pustaka Utama.

23. Rohmadin, Sulthon. (2016). Strategi Pengembangan Kawasan Wisata Berbasis Pembangunan Berkelanjutan di Kabupaten Ende Provinsi Nusa Tenggara Timur. Jurnal Politik Pemerintahan, 9(1): 141-153.

24. Sanjaya, Rindo Bagus. (2018). Strategi Pengembangan Pariwisata Berbasis Masyarakat di Desa Kemetul, Kabupaten Semarang. JUMPA, 05(01): 91-110.

25. Sugianti, Desy. (2016). Strategi Pengembangan Kawasan Wisata Pasar Terapung Berbasis Kearifan Lokal di Kota Banjarmasin. TATA KELOLA SENI, 2(2): 20-34. 
26. Sugiyono. (2012). Metode Penelitian Kuantitatif, Kualitatif and R\&D. Bandung: Penerbit Alfabeta.

27. Suharto. (2016). Strategi Pengembangan Wisata Agro di Banyuwangi. Jurnal IImiah Pariwisata-STP Trisakti, 21(1).

28. Susianti, Novia. (2017). Government Strategy in the Eradication of Dengue Hemorrhagic Fever (DHF) in Jambi City. Jurnal Bina Praja, 9 (2): 243 - 253.

29. Sutrisno, Ellen R., Charles R. Ngangi, and Caroline B. D. Pakasi. 2018. ANALISIS Strategi Pengembangan Pariwisata Kawasan Selat Lembeh di Kota Bitung. AgriSosioEkonomi Unsrat, 14(2): 95 - 110.

30. Swapna, B. (2018). Cultivation and Marketing of Tuberose (Lily) Flowers by the Rural Poor: An Approach of Swot Analysis. International Journal of Agriculture, Environment and Biotechnology, 11(1): 137-140.

31. Tatali, Aldy Adrianus, Ridwan Lasabuda, Jardie A. Andaki, and Bet E. S. Lagarense. (2018). Strategi Pengembangan Pariwisata Pesisir di Desa Bentung Kabupaten Kepulauan Sangihe Provinsi Sulawesi Utara. J. Kebijakan Sosek KP, 8(1): 53-62.

32. Wilopo, Khusnul Khotimah and Luchman Hakim. (2017). Strategi Pengembangan Destinasi Pariwisata Budaya (Studi Kasus pada Kawasan Situs Trowulan sebagai Pariwisata Budaya Unggulan di Kabupaten Mojokerto). Jurnal Administrasi Bisnis (JAB), 41(1): 56-65. 